University of Nebraska - Lincoln

DigitalCommons@University of Nebraska - Lincoln

Agronomy \& Horticulture -- Faculty Publications

Agronomy and Horticulture Department

6-1969

\title{
Contamination in Denta Sweetclover During Successive Generations of Seed Increase
}

H. J. Gorz

University of Nebraska-Lincoln

Francis A. Haskins

University of Nebraska-Lincoln, fhaskins@neb.rr.com

Follow this and additional works at: https://digitalcommons.unl.edu/agronomyfacpub

Part of the Plant Sciences Commons

Gorz, H. J. and Haskins, Francis A., "Contamination in Denta Sweetclover During Successive Generations of Seed Increase" (1969). Agronomy \& Horticulture -- Faculty Publications. 282.

https://digitalcommons.unl.edu/agronomyfacpub/282

This Article is brought to you for free and open access by the Agronomy and Horticulture Department at DigitalCommons@University of Nebraska - Lincoln. It has been accepted for inclusion in Agronomy \& Horticulture -Faculty Publications by an authorized administrator of DigitalCommons@University of Nebraska - Lincoln. 


\title{
Contamination in Denta Sweetclover During
}

\section{Successive Generations of Seed Increase ${ }^{1}$}

\author{
H. J. Gorz and F. A. Haskins ${ }^{2}$
}

\begin{abstract}
Contamination levels observed in the brceder, foundation, and certified seed generations of 'Denta' sweetclover (Melilotus alba Desr.) were 0.71, 1.69, and 3.62\%, respectively, as measured by the frequency of plants high in content of o-hydroxycinnamic acid. Based on a sam. ple of plants tested simultaneously for o-hydroxycinnamic acid content and $\beta$-glucosidase activity, a small but consistent decrease in the frequency of $c u$ plants occurred with succeeding seed generations, while shifts in the frequency of $b$ plants were not consistent in magnitude or direction. Contamination through cross-pollination with $\mathrm{CuCuBB}$ plants may be the major factor responsible for the observed decreases in the frequency of $c u$ plants.
\end{abstract}

Additional index words: Seed contamination, Genetic shift, o-hydroxycinnamic acid.

SIFTS in gene frequencies during the seed produc$\mathcal{S}$ tion sequence can drastically alter the genetic purity of crop varieties. In improved varieties of forage crops, such shifts are most common when the varieties are grown in specialized seed producing areas outside the normal areas of adaptation. Marked changes in location of seed production or in management practices, when superimposed on the high degree of genetic variability and cross-pollinating habit of most forage crops, encourage maximum genetic shifts.

Changes in varietal characteristics have been found in alfalfa (Medicago sativa L.) $(3,14,15)$, red clover (Trifolium pratense L.) $(2,18,19)$, Ladino clover $(T$. repens $\mathrm{L}$.) $(10,11,16,17)$, and sweetclover (Melilotus alba Desr.) (4) when different seed sources or generations were compared. Most of these studies have shown that varietal changes are due primarily to differential contributions by the clones or genotypes making up a variety to the total seed produced at a specified location or under a specific management system. Many of the studies have relied upon quantitatively inherited characteristics such as yield, height, maturity, and winter survival for detecting genetic shifts. Useful data have been obtained, but precise measures of genetic shifts are difficult in such studies because effects of individual genes cannot be observed in quantitative traits.

In most forage crops, a scarcity of reliable genetic markers has made precise measurements of genetic shifts impossible. However, simply inherited and easily identifiable marker genes have been used for study of gene frequency changes in Ladino clover and sweetclover. Portz and Jackobs (13) studied the frequency of cyanophoric plants from 235 seedlots of cer-

\footnotetext{
${ }^{1}$ Contribution from the Crops Research Division, Agricultural Research Service, U. S. Department of Agriculture, and the Nebraska Agricultural Experiment Station, Lincoln 68503. Supported in part by the National Science Foundation (Grant No. GB-1148). Published with the approval of the Director as Paper No. 2475, Journal Series, Nebraska Agr. Exp. Sta. Received Dec. 20, 1968.

${ }^{2}$ Research Geneticist, Crops Research Division, Agricultural Research Service, U. S. Department of Agriculture, and Bert Rodgers Professor of Agronomy, University of Nebraska.
}

tified Ladino clover produced in four western states. The frequency of plants containing both the cyanoglucoside and enzyme varied from 0 to $43 \%$ between seed lots obtained from one state, and the occurrence of plants with the cyanoglucoside alone varied from 0 to $67 \%$. Three possible reasons for these wide differences were suggested: (a) differences in the original seed lots, (b) genetic shift due to natural selection, and (c) outcrossing to other white clovers. Alternatives (a) and (c) were eliminated by Stanford et al. (16) in an investigation of gene frequency changes in Pilgrim Ladino clover. Differences in date of first flower and intensity of flowering were attributed to genetic shift, but a study of the genes producing the cyanoglucoside, its hydrolyzing enzyme, red flecking on the leaf, and V-leaf marking showed no strongly consistent changes in gene frequency with advance in generation.

Goplen and Weber (4), using a recessive genetic marker for low-coumarin content, determined contamination levels in Cumino sweetclover through four generations of seed increase. Mean contamination levels of $0.27 \%, 1.11 \%, 4.21 \%$ and $19.80 \%$ were found for breeder, foundation, registered, and certified seed, respectively. Cross-pollination with pollen from highcoumarin plants in nearby areas was suspected as the major factor in the rapid increase in contamination, although the lower inherent seedling vigor and seed yield of Cumino compared to the contaminants may have been responsible. Contamination by volunteer plants, admixtures of seed, or preferential fertilization was not significant.

This paper deals with changes in the phenotypic distribution of plants differing with respect to the $C u / c u$ and $B / b$ allelic pairs in successive generations of seed increase in Denta sweetclover, a variety low in $o$-hydroxycinnamic acid content. The $C u / c u$ alleles influence the content of o-hydroxycinnamic acid glucosides and are independent of the $B / b$ alleles which determine the presence or absence of $\beta$-glucosidase activity. Plants of the $C u C u$ genotype are high in content of o-hydroxycinnamic acid glucosides, and preparations of the $B B$ genotype possess $\beta$-glucosidase activity. The $C u$ and $B$ genes are both lacking in dominance $(7,9)$.

\section{MATERIALS AND METHODS}

Breeder seed of 'Denta', produced at the Wisconsin Agricultural Experiment Station in Madison, Wisconsin, constituted the initial stock in these investigations. The five lots each of foundation and certified seed were produced in North and South Dakota, where sweetclover is a well-adapted legume. A 250 - to $500-\mathrm{g}$ sample was obtained from each lot of seed. ${ }^{3}$

Each sample of seed was thoroughly mixed, and a portion was scarified for planting. Plantings were made in rows approximately $5 \mathrm{~cm}$ apart in $35-\times 50-\mathrm{cm}$ wooden flats containing

\footnotetext{
${ }^{3}$ The authors express their appreciation to J. D. Colburn of the South Dakota Crop Improvement Association and R. L. Harrison and D. C. Ebeltoft of North Dakota State University for providing the foundation and certified seed samples used in this study.
} 
a mixture of composted soil and sand. Approximately 500 to 700 seeds were planted in each flat; six flats were planted from each seed lot. Plants were grown in a greenhouse for approximately 2 to 3 months under natural illumination supplemented with incandescent light to provide an 18-hour photoperiod.

When most plants were at an early bud stage, a portion of a leaflet from each plant was tested qualitatively for o-hydroxycinnamic acid. The paper test employed was similar to that previously described for unheated samples (6), except that a drop of $\beta$-glucosidase preparation was added to each sample spot as soon as an entire sheet of samples had been taken. This procedure insured the hydrolysis of $c i s-o$-hydroxycinnamic acid glucoside in those samples lacking endogenous $\beta$-glucosidase activity, and thus permitted the accurate classification of $\mathrm{Cu}$ and cucu plants regardless of constitution with respect to the $B / b$ alleles. To promote the presence of a high proportion of cis-o-hydroxycinnamic acid glucoside in $\mathrm{Cu}$ - plants, and thereby assure a clear distinction between $\mathrm{Cu}$ - and cucu individuals, testing was done only on sunny days preceded by a full day of sunlight (8).

In a portion of the plants from most seed lots, a qualitative assay for $\beta$-glucosidase activity was done simultaneously with the qualitative test for $o$-hydroxycinnamic acid, by means of a second sample spot taken from the same leaflet as the first sample. This procedure also was similar to that previously described for unheated samples (6), except that a drop of sweetclover leaf extract containing cis-o-hydroxycinnamic acid glucoside (approximately $1 \mathrm{mg} / \mathrm{ml}$ ) was added to the sample spot. By this means, $B$ - plants were readily distinguished from $b b$ plants.

\section{RESULTS AND DISCUSSION}

There was a small but steady increase in contamination of Denta seed lots in succeeding generations as measured by the frequency of $C u$ plants (Table 1). The increase was slightly more than two-fold for both the foundation and certified seed classes, compared to the breeder and foundation classes, respectively. The range of contamination in the lots of certified seed is well within the reported tolerance limits of $10 \%$ for cattle (5) and 25\% for sheep (12). However, the values observed for the foundation and certified seed classes are considerably above the maximum levels allowed by the International Crop Improvement Association (I).

Simultaneous testing of plants for o-hydroxycinnamic acid content and $\beta$-glucosidase activity produced the data on phenotypic numbers presented in Table 2. These data permitted calculation of the phenotypic frequencies shown in Table 3. The chi-square test was used to determine whether or not the observed changes in frequency were significant. In applying this test the assumption was made that no shifts in phenotypic frequency should occur with suceeding generations. Thus, the frequencies observed in the breeder and foundation generations were used, before rounding to the extent shown in Table 3, to calculate expected numbers in the foundation and certified generations, respectively. These expected numbers were then compared with observed numbers in the foundation and certified generations. In this comparison, observed and expected numbers differed at the $1 \%$ level of probability in every instance except that involving the observed numbers of $B$ and $b$ individuals in the certified generation (Table 4). Accordingly, the decrease in frequency of $c u$ plants and the corresponding increase in the $C u$ phenotype, although small, appear to be significant. By comparison, changes in the frequencies of the $b$ and $B$ phenotypes were less consistent, both in direction and magnitude.

By calculating the products of appropriate pairs of the phenotypic frequencies in Table 3 , the expected
Table 1. Size of sample and degree of contamination in breed. er, foundation, and certified seed lots of Denta sweetclover.

\begin{tabular}{|c|c|c|c|c|c|}
\hline \multirow{2}{*}{\multicolumn{2}{|c|}{$\begin{array}{c}\text { Class of seed } \\
\text { and year }\end{array}$}} & \multirow{3}{*}{$\begin{array}{c}\text { Lot } \\
\text { no. } \\
\mathrm{B}-1 \\
\mathrm{~B}-2 \\
\mathrm{~B}-3\end{array}$} & \multirow{3}{*}{$\begin{array}{c}\begin{array}{c}\text { No. } \\
\text { plants } \\
\text { tested }\end{array} \\
2,426 \\
4,082 \\
2,192\end{array}$} & \multicolumn{2}{|c|}{$\begin{array}{l}\text { Cu plants } \\
\text { observed }\end{array}$} \\
\hline & & & & \multirow{2}{*}{$\begin{array}{r}\text { No. } \\
35 \\
21 \\
6\end{array}$} & \multirow{2}{*}{$\begin{array}{c}\% \\
1.44 \\
0.51 \\
0.27\end{array}$} \\
\hline Breeder & $\begin{array}{l}1960 \\
1962 \\
1966\end{array}$ & & & & \\
\hline & Total & & 8,700 & 62 & 0.71 \\
\hline \multirow[t]{2}{*}{ Foundation } & $\begin{array}{l}1962 \\
1962 \\
1963 \\
1965 \\
1965\end{array}$ & $\begin{array}{l}F-1 \\
F-2 \\
F-3 \\
F-4 \\
F-5\end{array}$ & $\begin{array}{r}2,279 \\
2,892 \\
3,488 \\
1,068 \\
362\end{array}$ & $\begin{array}{r}57 \\
42 \\
47 \\
19 \\
5\end{array}$ & $\begin{array}{l}2.50 \\
1.45 \\
1.35 \\
1.78 \\
1.38\end{array}$ \\
\hline & Total & & 10,089 & 170 & 1.69 \\
\hline \multirow[t]{2}{*}{ Certified } & $\begin{array}{l}1964 \\
1964 \\
1964 \\
1964 \\
1965\end{array}$ & $\begin{array}{l}\text { C-1 } \\
C-2 \\
\text { C-3 } \\
\text { C-4 } \\
\text { C-5 }\end{array}$ & $\begin{array}{l}3,866 \\
3,826 \\
3,353 \\
2,631 \\
1,066\end{array}$ & $\begin{array}{r}89 \\
132 \\
114 \\
160 \\
38\end{array}$ & $\begin{array}{l}2.30 \\
3.45 \\
3.40 \\
6.08 \\
3.56\end{array}$ \\
\hline & Total & & 14,742 & 533 & 3.62 \\
\hline
\end{tabular}

Table 2. Distribution of $\mathrm{CuB}, \mathrm{Cub}, \mathrm{cuB}$, and $c u b$ phenotypes in breeder, foundation, and certified seed classes of Denta sweetclover.

\begin{tabular}{lccccccc}
\hline $\begin{array}{l}\text { Class of } \\
\text { seed }\end{array}$ & $\begin{array}{c}\text { No. lots } \\
\text { sampled }\end{array}$ & $\begin{array}{c}\text { No. plants } \\
\text { tested }\end{array}$ & & \multicolumn{4}{c}{ Observed numbers } \\
\cline { 5 - 8 } & 3 & $\mathbf{3 , 8 8 4}$ & & CuB & Cub & cuB & cub \\
\hline $\begin{array}{l}\text { Breeder } \\
\text { Foundation }\end{array}$ & 3 & 2,230 & & 40 & 18 & 1,968 & 1,888 \\
Certified & 5 & 8,789 & & 266 & 71 & 1,184 & 991 \\
\hline
\end{tabular}

Table 3. Frequencies of four phenotypes in three seed classes of Denta sweetclover.

\begin{tabular}{cccc} 
& & \multicolumn{3}{c}{ Observed frequency } \\
\cline { 2 - 4 } Phenotype & Breeder & Foundation & Certified \\
\hline$\underline{\mathrm{Cu}}$ & 0.007 & 0.025 & 0.038 \\
$\underline{\underline{\mathrm{u}}}$ & 0.993 & 0.975 & 0.962 \\
$\underline{\mathrm{B}}$ & 0.509 & 0.549 & 0.540 \\
$\underline{\mathrm{b}}$ & 0.491 & 0.451 & 0.460 \\
\hline
\end{tabular}

Table 4. Chi-square values for comparison of observed phenotypic distributions with expected distributions based on no outside contamination.

\begin{tabular}{|c|c|c|c|}
\hline \multirow{2}{*}{$\begin{array}{l}\text { Expected distribution } \\
\text { based on phenotypic } \\
\text { frequencies in }\end{array}$} & \multirow{2}{*}{$\begin{array}{l}\text { Observed } \\
\text { distribution } \\
\text { in }\end{array}$} & \multicolumn{2}{|c|}{$\begin{array}{l}\mathrm{X}^{2} \text { values for phenotypic } \\
\text { classification according to }\end{array}$} \\
\hline & & $\underline{\mathrm{cu}}$ and $\mathrm{Cu}$ & $\underline{b}$ and $\underline{B}$ \\
\hline $\begin{array}{l}\text { Breeder } \\
\text { Foundation }\end{array}$ & $\begin{array}{l}\text { Foundation } \\
\text { Certified }\end{array}$ & $\begin{array}{l}94.89 * * \\
68.37 * *\end{array}$ & $\begin{array}{l}14.00^{* *} \\
2.95\end{array}$ \\
\hline
\end{tabular}

frequencies and numbers of the $C u B, C u b, c u B$, and $c u b$ phenotypes were determined for each seed generation. The chi-square test was then used to compare these expected values with the actual numbers from Table 2. Chi-square values of 2.61 $(0.4<\mathrm{P}<0.5), 7.25$ $(0.05<\mathrm{P}<0.07)$, and $87.86 \quad(\mathrm{P}<0.0001)$ were obtained for the breeder, foundation, and certified generations, respectively. The increases in chi-square values with succeeding generations are due primarily to the relatively large excess of $C u B$ plants and the deficiency of $C u b$ plants in comparison with expected numbers.

The most reasonable explanation for the excess of $C u B$ plants is that during production of the certified seed, pollination with foreign pollen from plants of the $C u C u B B$ genotype occurred. Nearby fields of sweetclover or volunteer plants in roadsides and waste areas are probable sources of such foreign pollen. Essentially all volunteer plants and commercially grown varieties of Melilotus alba in the United States at the time this study was in progress were of the $C u C u B B$ genotype. Goplen and Weber (4) also concluded that cross-pollination was a major factor in the contamination of Cumino sweetclover. They suggested that the lower seedling vigor and seed yield of Cumino also may have contributed to the rapid increase in con- 
tamination. The latter explanation does not apply as readily to Denta, which has good seedling vigor and seed yield.

It is apparent that contamination of insect-pollinated crop varieties can occur during seed increase despite adherence to current regulations designed to maintain the genetic purity of those varieties. The present study cannot serve as a basis for predictions of the contamination that is likely to occur during seed increase of other insect-pollinated crops; the predominant pollinating insects, isolation distances, and environmental factors will differ from those prevailing in the production of sweetclover seed. Thus, the need is apparent for marker genes by which precise measurements of contamination can be obtained. The need is particularly acute in those crops where levels of contamination are known, beyond which the performance or utilization of the variety will be adversely affected in some manner. The development of standards for individual crops, supported by studies such as the one reported here, would appear to be highly desirable wherever possible.

\section{LITERATURE CITED}

1. Anonymous. 1963. Minimum Seed Certification Standards. Int'l Crop Impr. Assoc. Publ. No. 20.

2. Beard, D. F., and E. A. Hollowell. 1952. The effect on performance when seed of forage crop varieties is grown under different environmental conditions. Proc. VI Int'l. Grassl. Cong. 1:860-866.

3. Bula, R. J., and C. S. Garrison. 1962. Fall regrowth response of Ranger and Vernal alfalfa as related to generations of increase and area of seed production. Crop Sci. 2:156-159.

4. Goplen, B. P., and R. P. Weber. 1966. Progressive contamination in low-coumarin sweetclover during varietal increase. Proc. X Int'l Grassl. Cong., pp. 698-704.

5. - - J. J. H. Linton, and J. M. Bell. 1964. Dicoumarol studies. III. Determining tolerance limits of contamination in low-coumarin sweetclover varieties using a cattle bioassay. Can. J. Animal Sci. 44:76-86.

6. Gorz, H. J., and F. A. Haskins. 1958. Rapid tests for free and bound coumarin in sweetclover. Agron. J. 50:211-214.

7. - _ - and - _-. 1969. Absence of dominance of the $C u$ gene in influencing o-hydroxycinnamic acid content in Melilotus alba. Crop Sci. 9:79-81.

8. ______ _ and A. Kleinhofs. 1966. Genetic and biochemical aspects of $o$-hydroxycinnamic acid synthesis in Melilotus alba. Proc. X Int'l GrassI. Cong., pp. 704-708.

9. Haskins, F. A., and H. J. Gorz. 1965. Absence of dominance of the $B$ gene in influencing $\beta$-glucosidase activity in Melilotus alba. Genetics 51:733-738.

10. Jackobs, J. A., and C. N. Hittle. 1958. Variations among seedlots of certified Ladino clover and other white clovers. Agron. J. 50:327-330.

11. Laude, H. M., E. H. Stanford, and J. A. Enloe. 1958. Photoperiod, temperature and competitive ability as factors affecting seed production of selected clones of Ladino clover. Agron. J. 50:223-225.

12. Linton, J. H., B. P. Goplen, J. N. Bell, and L. B. Jaques 1963. Dicoumarol studies. II. The prothrombin time response of sheep to various levels of contamination in lowcoumarin sweetclover varieties. Can. J. Animal Sci. 43:353360 .

13. Portz, H. L., and J. A. Jackobs. 1955. Differences between seed lots of Ladino clover in cyanophoric properties. Agron. J. 47:143-145.

14. Smith, D. 1955. Influence of area of seed production on the performance of Ranger alfalfa. Agron. J. 47:201-205.

15. - - - 1 1958. Performance of Narragansett and Vernal alfalfa from seed produced at diverse latitudes. Agron. J. 50:226-229.

16. Stanford, E. H., H. M. Laude, and P. de V. Booysen. 1962. Effects of advance in generation under different harvesting regimes on the genetic composition of Pilgrim Ladino clover. Crop Sci. 2:497-500.

17. - - - - and J. A. Enloe. 1960. Effect of harvest dates and location on the genetic composition of the Syn 1 generation of Pilgrim Ladino clover. Agron. J. 52:149-152.

18. Steppler, H. A., and L. C. Raymond. 1954. Note on the management of red clover for seed production. Can. J. Agr. Sci. 34:222-224.

19. Valle, O. 1960. Experiences with seed production of Northern European forage crops grown at various latitudes in North America. Proc. VIII Int'l. Grassl. Cong., pp. 185-188. 